\title{
Bovine cryptosporidiosis: impact, host-parasite interaction and control strategies
}

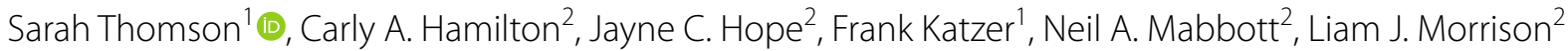
and Elisabeth A. Innes ${ }^{1 *}$

\begin{abstract}
Gastrointestinal disease caused by the apicomplexan parasite Cryptosporidium parvum is one of the most important diseases of young ruminant livestock, particularly neonatal calves. Infected animals may suffer from profuse watery diarrhoea, dehydration and in severe cases death can occur. At present, effective therapeutic and preventative measures are not available and a better understanding of the host-pathogen interactions is required. Cryptosporidium parvum is also an important zoonotic pathogen causing severe disease in people, with young children being particularly vulnerable. Our knowledge of the immune responses induced by Cryptosporidium parasites in clinically relevant hosts is very limited. This review discusses the impact of bovine cryptosporidiosis and describes how a thorough understanding of the host-pathogen interactions may help to identify novel prevention and control strategies.
\end{abstract}

\section{Table of contents}

1 Introduction

1.1 Parasite life cycle

2 Bovine cryptosporidiosis

2.1 Prevalence

2.2 Economic and production impact

2.3 Zoonotic implications

2.4 Environmental impacts

3 Current control measures for bovine cryptosporidiosis

3.1 Farm management practices

3.2 Therapeutics

3.2.1 Livestock

3.2.2 Vaccines

4 Immunology of cryptosporidiosis

4.1 Innate immune response

\subsubsection{Epithelial cells}

4.1.2 Natural killer (NK) cells

4.1.3 $\gamma \delta$ T cells

4.1.4 Dendritic cells (DCs)

4.1.5 Macrophages

4.2 Adaptive immune response

4.2.1 CD4+ T cells

4.2.2 Th1 immune responses

4.2.3 Th2 immune responses

4.2.4 Th17 immune responses

4.2.5 CD8+ T cells

4.2.6 B cells

4.2.7 Models to study the interaction between Cryptosporidium and the host

5 Concluding remarks

\footnotetext{
*Correspondence: lee.innes@moredun.ac.uk

†Sarah Thomson and Carly A. Hamilton are joint first authors

${ }^{1}$ Moredun Research Institute, Pentlands Science Park, Bush Loan,

Edinburgh EH26 OPZ, Scotland, UK

Full list of author information is available at the end of the article
} 


\section{Introduction}

Cryptosporidium parvum was first described in 1907 by Edward Ernst Tyzzer in the small intestine of mice [1]. Since then, over 30 species of Cryptosporidium have been described that infect a wide range of host species [2]. Several species infect cattle and have a significant impact upon animal health and production, especially in young calves. Unfortunately, relatively few tools are available to combat bovine cryptosporidiosis (no vaccine and one drug of limited utility), and our knowledge of host-pathogen interactions in the bovine host is also very limited. Addressing these important gaps in our understanding of bovine cryptosporidiosis will aid the development of interventions going forward. This review summarises our current understanding of bovine cryptosporidiosis, with a particular focus on what is currently known about the bovine immune response to this pathogen, and discusses avenues for new research to further our understanding of host-parasite interactions in bovine cryptosporidiosis.

Cryptosporidiosis was first reported in cattle in the early 1970s [3], but the observed clinical disease could not be solely attributed to Cryptosporidium as there was evidence of co-infection with other viral and bacterial pathogens. In 1983, neonatal diarrhoea in experimentally infected calves was reported with Cryptosporidium species as the single infective agent [4]. Cryptosporidiosis is now recognised as endemic in cattle worldwide and is one of the most important causes of neonatal enteritis in calves globally [5-7]. Veterinary surveillance reports show cryptosporidiosis has been the main diagnosed cause of enteritis in calves in the UK between 2007 and 2011 (Figure 1) [8].

\subsection{Parasite life cycle}

Cryptosporidium oocysts are transmitted between hosts via the faecal-oral route, either directly via contact with faeces from infected hosts, or indirectly through environmental contamination or ingestion of contaminated food or water. Following ingestion of infective Cryptosporidium oocysts by the host, the conditions in the gastrointestinal tract (low $\mathrm{pH}$ and body temperature) trigger oocyst excystation and four sporozoites are released (Figure 2A). Cryptosporidium parvum sporozoites adhere to epithelial cells (Figure 2B) of the ileum, specifically at the

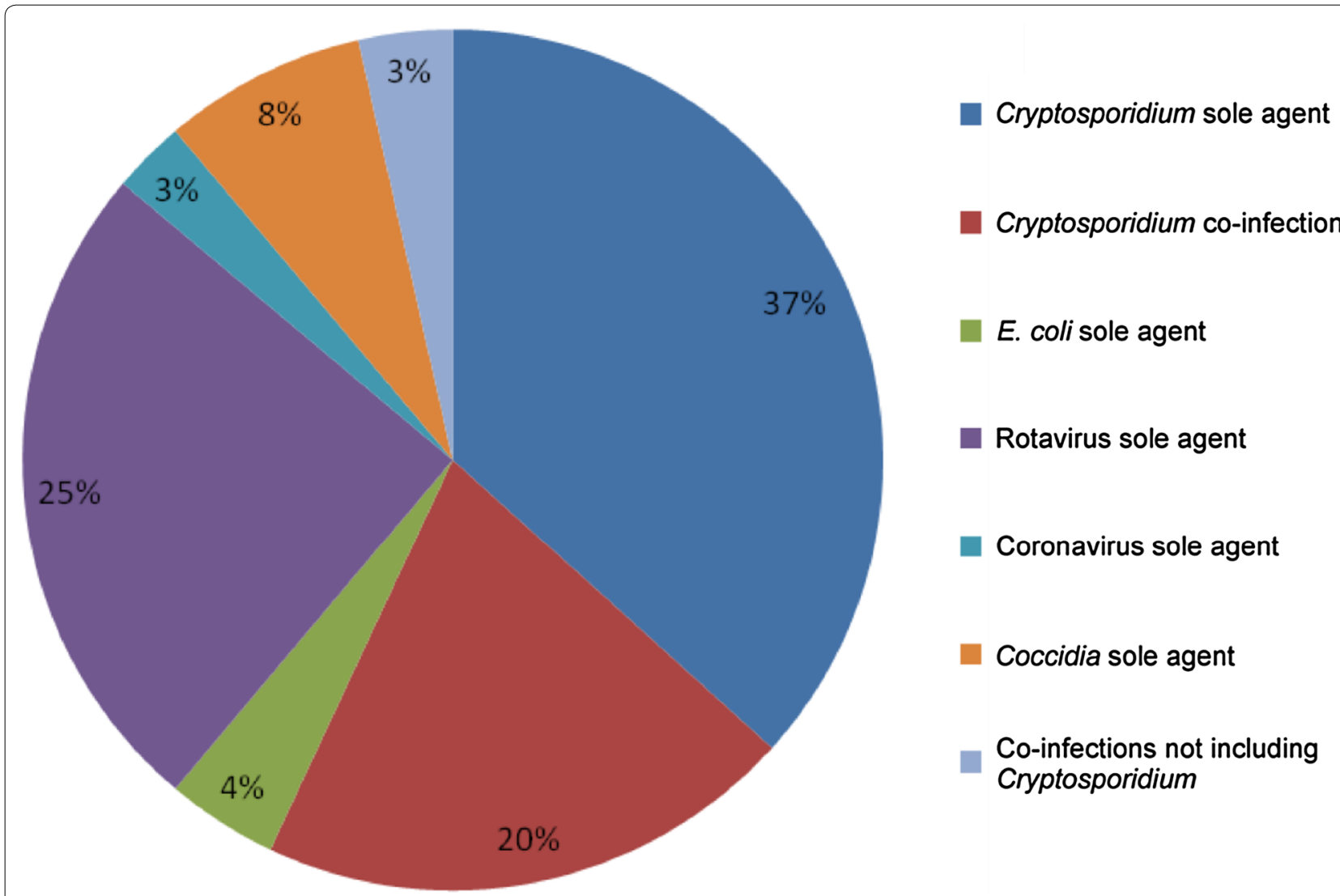

Figure 1 Pathogens causing diarrhoea in young calves. Cryptosporidium is the most commonly detected pathogen causing diarrhoea in calves less than 1 month of age as a proportion of diagnosable submissions 2007-2011 (veterinary investigation diagnosis analysis [VIDA]). 
ileocaecal junction in the case of C. parvum. Following attachment, the sporozoites become incorporated within a parasitophorous vacuole formed by the host cell membrane yet remain extracytoplasmic. A feeder organelle, unique to Cryptosporidium and present in all intracellular stages, acts as the interface between the parasite and the host cell. The feeder organelle enables the parasite to obtain all necessary nutrients from the host while still being protected from the host immune response and hostile gut conditions (Figure 3).

After the development of the feeder organelle the sporozoite itself becomes more spherical in shape and forms a trophozoite (Figure $2 \mathrm{C}$ ). The parasite begins asexual reproduction (Figure 2D) and develops into a type I meront (Figure 2E) which releases merozoites. The merozoites that are formed within the type I meront can immediately re-infect the host, by invading neighbouring epithelial cells and beginning asexual reproduction again, or develop into a type II meront.
Type II meronts release four merozoites that initiate the sexual reproductive cycle. The released merozoites invade host cells and differentiate into either macrogamonts (Figure 2H) or microgamonts (Figure 2G). Microgamonts develop multiple nuclei and release free microgametes that penetrate and fertilise the macrogamete, producing a zygote (Figure 2I). Meiosis occurs and the zygote differentiates into four sporozoites as the oocyst develops and is released from the lumen.

The sporozoites may be released directly into the lumen either from thin-walled oocysts (Figure 2K) that re-infect the host, or are contained in thick-walled oocysts (Figure 2J) which are shed in faeces and are immediately infective for other hosts [10]. The ability to produce thin-walled oocysts which enable auto-infection of the host is one of the reasons why the Cryptosporidium parasite is so successful. This auto-infection means that the parasite can produce many new oocysts in a relatively short time.

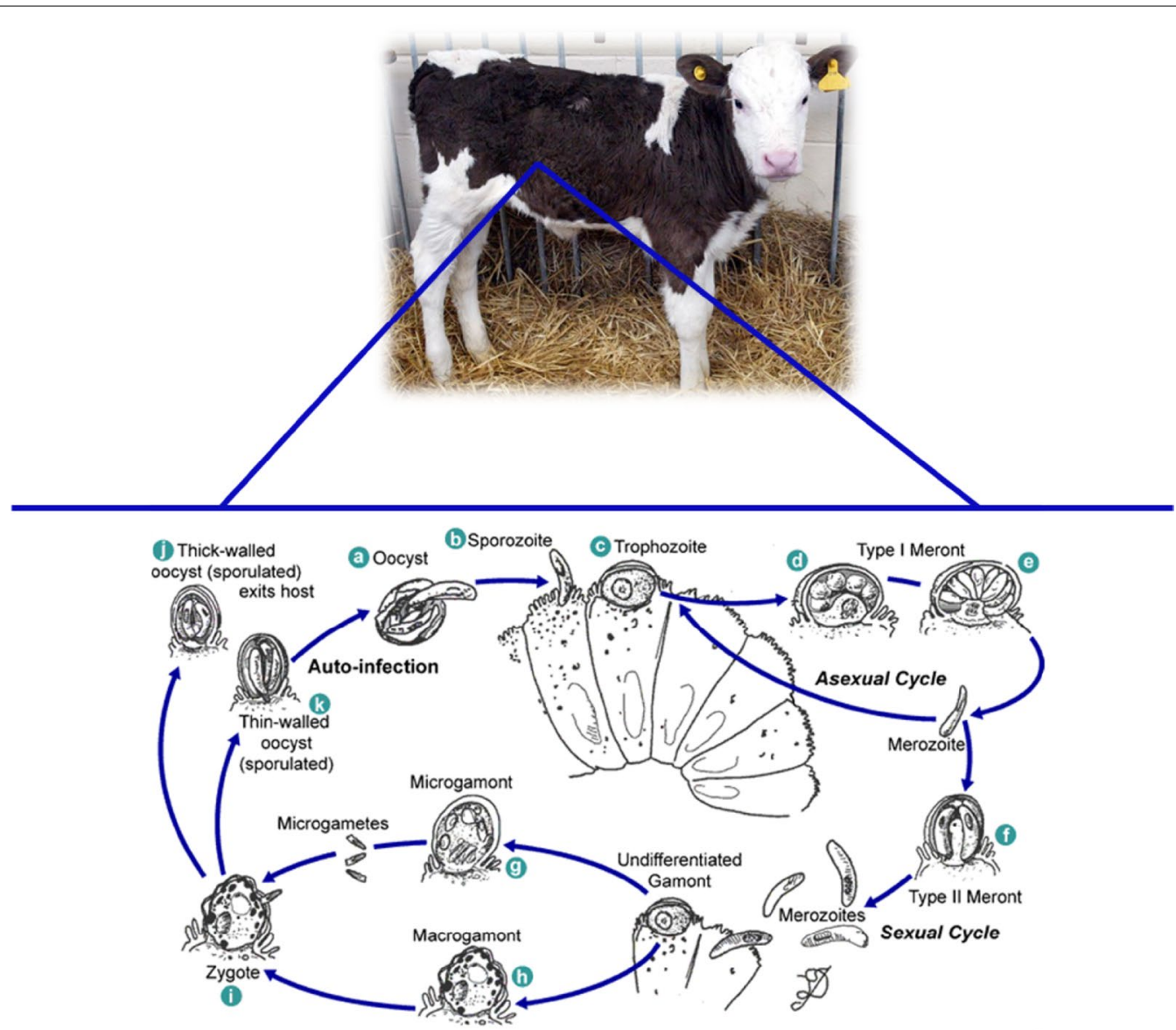

Figure 2 Life cycle of Cryptosporidium. Ingested sporulated oocysts release four sporozoites that invade host epithelial cells and develop into trophozoites, before undergoing asexual and sexual reproduction, resulting in the generation of both thin and think walled oocysts. Thin-walled oocysts auto-infect epithelial cells and thick-walled oocysts are excreted in the faeces of the host. Reproduced from [9]. 


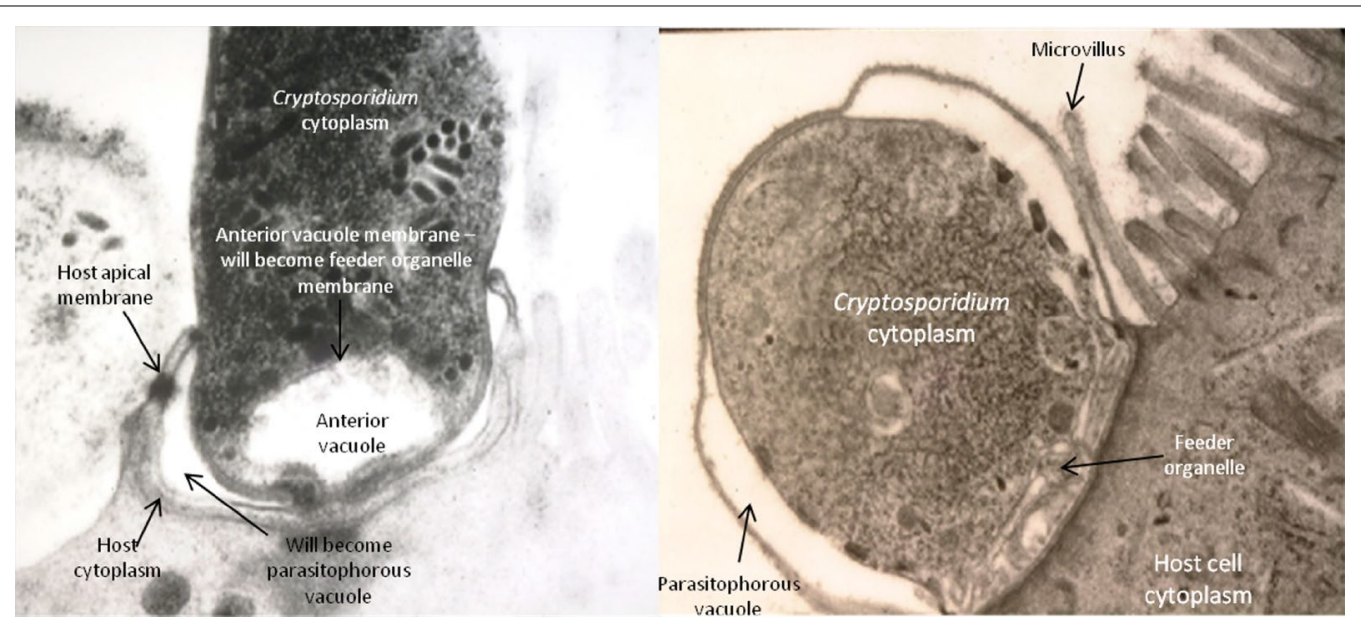

Figure 3 Parasite invasion in host cells. Images illustrate a Cryptosporidium sporozoite invading host epithelial cells (left) and a Cryptosporidium trophozoite within the parasitophorous vacuole (right). Images by kind permission of Saul Tzipori.

Thick-walled sporulated oocysts are excreted by infected hosts and are very resistant to many environmental conditions $[11,12]$. Oocysts survive for several months in cool, moist climates, but can be inactivated by desiccation [13]. Environmental contamination and oocyst persistence is a significant factor in the epidemiology of bovine cryptosporidiosis.

\section{Bovine cryptosporidiosis}

Four species of Cryptosporidium are commonly found in cattle: C. parvum, C. bovis, C. ryanae and C. andersoni, but only C. parvum is associated with clinical disease in neonatal calves $[14,15]$, with older animals (> 6 weeks) exhibiting asymptomatic shedding of oocysts.

There tends to be an age-related distribution [16] of these species with $C$. parvum, C. bovis and C. ryanae infecting the small intestine of weaned calves. Cryptosporidium bovis and C. ryanae have not yet been associated with clinical disease in any age group of cattle although one study from Sweden reported the presence of $C$. bovis as a single pathogen in diarrhoeal samples $(\mathrm{n}=6)$ from calves aged $>21$ days, this suggests that $C$. bovis may have pathogenic potential [17]. Cryptosporidium andersoni is more frequently found in adult cattle then younger animals and infects the abomasum [18]. The clinical signs associated with $C$. andersoni include a reduction in weight-gain and milk yield in adult cows [19].

One suggestion for the age-related distribution of Cryptosporidium species seen in several host species is that changes in the gut microflora as the animal matures or due to dietary changes may affect the ability of the parasite to infect the gut. While there are no experimental trials demonstrating this in cattle, Kvac et al. [21] investigated the age-related susceptibility of pigs to C. scrofarum; previous work had indicated that while C. suis infected all age groups of pigs it appeared that C. scrofarum only infected older animals [20]. In their study, groups of 4, 5, 6, 7 and 8 weeks-old naïve piglets were infected with C. scrofarum oocysts and faecal samples were collected and examined for the presence of oocysts. The study found that oocysts were only detected in the faeces of animals $>5$ weeks of age. Additionally, no parasite DNA was detected in the gut samples of the 4 week old pigs at post-mortem while C. scrofarum DNA was detected in the duodenum, ileum and jejunum of the older pigs. The authors suggested that changes to the gut at weaning, while the piglets were adapting to a new diet may make the gut easier for the parasite to invade [21].

Neonatal animals infected with C. parvum may suffer from profuse watery diarrhoea, inappetence, lethargy, dehydration and in some cases death can occur. The onset of diarrhoea usually occurs around 3-4 days after ingestion of infective oocysts and lasts for approximately 1-2 weeks. Oocyst shedding occurs between 4 and 12 days post-infection though this can vary depending on the initial challenge dose [22] and oocyst shedding is not always associated with diarrhoea. Infected calves can shed large numbers (over $1 \times 10^{10}$ ) of oocysts each day [23], which are immediately infective to other susceptible hosts [23]. Very few C. parvum oocysts are required to cause infection in susceptible hosts, although evidence suggests this varies according to parasite isolate. As few as nine oocysts of the TAMU isolate caused disease when tested on human volunteers, whereas in the same study the infective dose was 87 and 1042 oocysts for the IOWA 
and UCP isolates, respectively [24]. A similar study in neonatal calves $(<24 \mathrm{~h}$ old), experimentally infected with C. parvum, demonstrated that as few as 17 oocysts were sufficient to cause diarrhoea and oocyst shedding [25]. Since naturally infected calves can shed in excess of $3 \times 10^{10}$ oocysts over a 6 day period [23], the ability of $C$. parvum to rapidly multiply in the gut and establish infection after exposure to a small number of oocysts makes cryptosporidiosis a difficult disease to control on farms.

\subsection{Prevalence}

Bovine cryptosporidiosis is widespread and has been reported as a major cause of calf enteritis [5-7] in many countries throughout the world [26-29]. The prevalence of C. parvum infection varies between countries and studies. For example, reported $C$. parvum prevalence rates of $C$. parvum in pre-weaned calves in the UK range from 28.0 to $80.0 \%$ [28, 30, 31]. Studies from other parts of the world have reported prevalence of C. parvum in pre-weaned calves from 3.4 to $96.6 \%$ [16, 32-38]. A longitudinal study carried out on a single farm in the USA which followed a group of calves $(\mathrm{n}=30)$ from birth to 24 months showed that $96.6 \%(29 / 30)$ of calves were positive for Cryptosporidium at 2 weeks of age [35]. This demonstrates the high likelihood that almost all calves on a farm become infected with Cryptosporidium in the first few weeks of life.

The variability in the reported prevalence of C. parvum most likely reflects differences in the design of the studies and the detection methods used. Animal age at the time of sampling is very important as calves aged $<6$ weeks are most likely to be shedding $C$. parvum while older animals may shed another (non-pathogenic) Cryptosporidium species $[14,15]$. The type of sample examined (diarrhoeic samples versus non-diarrhoeic), nature of the study (point-prevalence studies may underestimate prevalence) and the techniques employed to examine samples can have a significant impact on results. For example, one of the most common methods for veterinary diagnosis of cryptosporidiosis is microscopy. Though this one of the most cost-effective methods for detection of the parasite many microscopy methods require a degree of technical expertise and do not enable speciation of the parasite. Molecular tools are usually used in a research setting as these are much more sensitive and provide far more information about the parasite such as species and genotype [2]. Species can be differentiated using multiplex polymerase chain reaction (PCR) [39], restriction enzymes to digest PCR products into fragments of different sizes [PCR-restriction fragment length polymorphism (RFLP)] or by direct sequence analysis. Real-time PCR is can also be usedfor Cryptosporidium detection and can detect as few as 2 oocysts per PCR [40].
An advantage of real-time PCR is the ability to quantify parasite burden as standard PCR can only indicate the presence of parasite DNA but cannot quantify. During sample processing, a concentration step prior to microscopy or PCR can increase the likelihood of detecting the parasite [41, 42], particularly in large samples containing low oocyst numbers. It is important that the appropriate tools are utilised when investigating prevalence of Cryptosporidium as using less sensitive methods can lead to an underestimation.

\subsection{Economic and production impact}

The precise economic losses associated with bovine cryptosporidiosis have not thus far been examined in detail but include the cost of treatment and management of enteritis, reduced feed conversion and production efficiency and losses due to animal death. Research by the Scottish Agricultural College, which examined 212 calf diarrhoea (not necessarily only Cryptosporidium) outbreaks investigated by 20 veterinary practices, estimated that the typical cost associated with management of disease was a minimum of $£ 34$ per calf affected, excluding labour [43]. Considering that in some cases it is possible that almost all calves within a herd may suffer from diarrhoea this cost is not insignificant.

At present, studies looking at the long term effects of C. parvum infection in calves have not been carried out. However, Cryptosporidium infection can impair growth rates in humans, lambs and mice [44-47]. A cohort study of children from a slum community in Southern India which were infected with $C$. hominis, $C$. parvum or C. meleagridis showed that children that had suffered from multiple bouts of cryptosporidiosis in the first 2 years of life were significantly lighter and shorter than children who had only a single episode at 2 years of age. However, by 3 years of age there were no significant differences in height and weight between children who had suffered from single or multiple episodes of cryptosporidiosis [44]. An earlier study carried out on children aged $<3$ months in Peru also found that children infected with C. parvum were shorter and lighter than uninfected children. By 12 months after the onset of infection, children who had been infected were $1.05 \mathrm{~cm}$ shorter than their non-infected counterparts [45].

Very few studies have been carried out in livestock to determine the long term effects of cryptosporidiosis on growth. One study in Australia showed that lambs which were positive for Cryptosporidium were up to $1.65 \mathrm{~kg}$ lighter than uninfected lambs at slaughter [46]. A subsequent study involving $>1000$ lambs from eight farms in Australia reported that shedding of C. parvum preslaughter was associated with a lower carcass weight of up to $2.6 \mathrm{~kg}$ compared to lambs which did not shed 
C. parvum [48]. If a similar reduction in the long term growth of calves affected by Cryptosporidium also occurs, this may prove costly for farmers due to loss of income from lower carcass weights, treatment cost or additional feed costs required to get calves to market weight.

\subsection{Zoonotic implications}

Most human cases of cryptosporidiosis are caused by either the zoonotic species C. parvum or the human adapted species $C$. hominis [40]. Together these two species account for $>90 \%$ of human infections worldwide [49] and 96\% of clinical cases in the UK [50].

Cryptosporidiosis in humans can be found worldwide in many environments, particularly in developing countries with poor sanitary conditions [51, 52]. Children $(<4$ years of age) and the elderly are more susceptible to disease than young adults [53] with children tending to acquire the infection shortly after, or during weaning [54]. Although infection of immunocompetent people with Cryptosporidium tends to cause self-limiting diarrhoea, cryptosporidiosis is the second biggest cause (after rotavirus) of infant diarrhoea and death in Africa and Asia $[55,56]$. In 2010, it was demonstrated that diarrhoea accounted for $10.5 \%$ of the 7.6 million deaths of children under the age of 5 [57]. Therefore, diarrhoea caused by Cryptosporidium can result in a significant number of deaths in developing countries.

In the UK, zoonotic transmission of C. parvum peaks in the spring months [58] and is thought to be related to springtime calving and lambing, and an increase in people participating in outdoor activities at this time of year. Cases of cryptosporidiosis decreased in the spring of 2001 during the foot and mouth disease outbreak, most likely due to a reduction in the number of young farm animals and restrictions on farm animal movement [59, 60]. Zoonotic transmissions to veterinary students working in practice for the first time are also common [6164], in addition to outbreaks associated with petting zoos or farm visits $[65,66]$.

\subsection{Environmental impacts}

The rapid amplification of C. parvum within infected hosts results in the production of significant numbers of oocysts. In addition, the inherent properties of oocysts that cause them to persist in the environment, means that oocysts represent a significant environmental threat to human health. Since one of the most common methods of transmission of Cryptosporidium is via contaminated water, maintaining water supplies Cryptosporidium-free is a major challenge for relevant government agencies and water companies. In the UK, livestock pasture often surrounds catchment areas collecting water ultimately destined for drinking water. Outbreaks of cryptosporidiosis in humans have often been attributed to contamination of water catchments by cattle manure. The hardy nature of Cryptosporidium oocysts and their small size makes it difficult to eliminate them from drinking water, and contamination to a water supply can potentially lead to large numbers of people becoming infected. Each year, 400-900 laboratory-confirmed cases of cryptosporidiosis are reported to Health Protection Scotland (HPS) and 3000-6000 cases in England and Wales are reported to the Health Protection Agency (HPA) [67]. In England and Wales between 2000 and 2003 there were six drinking water associated outbreaks of cryptosporidiosis, two of which were associated with $C$. hominis affecting 18 and 28 people, one with both $C$. hominis and $C$. parvum affecting 133 people. The remaining three outbreaks were all associated with C. parvum and affected 47, 3 and 4 people respectively [58].

A recent study which analysed the species and genotypes of Cryptosporidium present within livestock and wildlife grazing on a water catchment area with a history of cryptosporidiosis revealed that farm livestock (cattle and sheep) and wildlife (red and roe deer) all shed the same species of Cryptosporidium (C. parvum) which was detected in the local water supply [30]. Genotyping results showed that livestock and wildlife also shared the same genotype of C. parvum illustrating that transmission of the parasite can occur between livestock and wildlife where grazing is shared.

Having a broad range of hosts that can shed millions of oocysts, combined with that fact that a low dose of hardy oocysts can result in disease in naïve hosts make this parasite very widespread and difficult to manage.

\section{Current control measures for bovine cryptosporidiosis}

Cryptosporidiosis is a difficult disease to control (due to environmentally stable oocysts, low infective dose and high levels of excreted sporulated oocysts) and infection may be transmitted to a group of susceptible hosts very quickly. The oocysts are resistant to many disinfectants $[49,68]$, there are no vaccines available to prevent the disease and available treatment options are limited and often rely on rehydration therapy [69].

\subsection{Farm management practices}

As the oocysts of C. parvum are very difficult to eliminate from the environment an alternative control measure is to try and reduce the environmental contamination in the first place. Frequent removal of faeces and contaminated bedding from calving areas and calf houses, combined with steam-cleaning and disinfection with a suitable disinfectant such as Hydrogen Peroxide based disinfectants can help to reduce environmental build up. 
Thorough cleaning with very hot water followed by drying [70] can also be effective as the oocysts are susceptible to extremes of temperature (down to $-20{ }^{\circ} \mathrm{C}$ and up to $60{ }^{\circ} \mathrm{C}$ ) and desiccation [13].

\subsection{Therapeutics}

At present, few products are licensed in the UK for the treatment or prevention of cryptosporidiosis in livestock or humans. Those which are available are not very effective, and in most cases will only reduce the duration of shedding and have little or no effect in immunocompromised patients.

\subsubsection{Livestock}

The only licensed treatment for cryptosporidiosis in calves is halofuginone lactate, the mechanism of action of this drug is unknown but it is thought to affect the merozoite and sporozoite stage of the parasite [71]. This drug is approved for use in both prevention and treatment of cryptosporidiosis in calves but cannot be used in animals have shown signs of diarrhoea for $>24 \mathrm{~h}$. As a prophylactic measure the drug should be given within $48 \mathrm{~h}$ of birth and as a therapeutic agent, within $24 \mathrm{~h}$ of the onset of symptoms. Halofuginone lactate must be given for 7 consecutive days, which can be difficult to manage, particularly for beef calves that are kept with their dams. Treatment with halofuginone lactate does not completely prevent or cure disease but can reduce oocyst shedding and the duration of diarrhoea [72-74]. There are no licensed treatments for cryptosporidiosis in sheep, goats or pigs.

Several other chemotherapeutic agents have been tested for the treatment of cryptosporidiosis in livestock but none have resulted in a significant reduction in clinical symptoms. For example, some antibiotics, such as paromomycin have shown efficacy against Cryptosporidium oocyst shedding, clinical disease and mortality in calves, lambs and goat kids, but these compounds are not registered for use in calves [75, 76]. Fayer and Ellis [75] showed that experimentally infected calves treated with $100 \mathrm{mg} / \mathrm{kg}$ paromomycin twice daily for 11 days shed significantly less oocysts than control (untreated) calves. Treated calves also showed a significant reduction in duration and severity of diarrhoea. A field trial to test the efficacy of paromomycin in naturally infected dairy calves showed similar results; ten dairy calves on a farm known to have a problem with cryptosporidiosis were treated with $100 \mathrm{mg} / \mathrm{kg}$ paromomycin once per day for 10 days while another group were left untreated. Treated calves showed no diarrhoea until after treatment was stopped while untreated calves began to develop diarrhoea after 7 days. The authors suggested that the treated calves only showed diarrhoea after treatment was stopped due to the continuous parasite challenge in a field environment. Oocysts were detected in faecal samples from all calves but the shedding of oocysts in treated calves was significantly later than in untreated calves [77].

A few coccidiostats, such as decoquinate have been tested against Cryptosporidium in neonatal calves with limited or no reduction in oocyst shedding [78]. Nitazoxanide which is the only licensed treatment for human cryptosporidiosis has also been tested on experimentally infected calves and was shown to reduce duration of oocyst shedding and severity of diarrhoea in treated calves [79] but at present it is not licensed for use in cattle.

More recent studies which have evaluated novel bumped kinase inhibitors (BKIs) as a potential treatment for bovine cryptosporidiosis showed that experimentally infected calves treated with BKIs had a reduction in oocyst shedding when compared with untreated controls. One study did not show any differences in diarrhoea between the groups but the authors noted that the clinical disease seen in the control animals was very mild [80]. In another study it was demonstrated that all three of the BKIs that were tested alleviated clinical symptoms of cryptosporidiosis (when calves were dosed twice daily for 5 days) but did not eliminate them completely [81].

\subsubsection{Vaccines}

Currently, there are no vaccines available to prevent cryptosporidiosis in either farm livestock or humans. However, several attempts to develop such a vaccine have been made, some of which were partially successful under experimental conditions. Calves that were immunised with killed ( $\gamma$-irradiated or lyophilised) C. parvum oocysts showed reduced oocyst shedding and diarrhoea when compared to non-immunised calves [82, 83]. However, this vaccine was not effective when tested under field conditions [84].

Infection with Cryptosporidium often occurs within the first week of life, so attempting to immunise the neonatal calves themselves is unlikely to be effective as this will not provide sufficient time to induce a significant immune response prior to infection [85]. To resolve this issue, attempts have been made to immunise pregnant cows to produce antibodies against Cryptosporidium which can be passed via colostrum to their calves. Calves receiving colostrum from cows vaccinated in this manner with recombinant $C$. parvum were protected against diarrhoea and also had reduced oocyst shedding, when compared to those calves that received colostrum from non-vaccinated cows [86]. However, a commercial vaccine has not so far become available as the efficacy of recombinant C. parvum has yet to be demonstrated in the field. 
Despite several compounds being tested for efficacy against cryptosporidiosis in calves, to date, no new drugs have reached the market since 1999 when halofuginone lactate was approved for use. It is necessary to carry out further research to better understand this parasite so that new treatment options can be developed.

\section{Immunology of cryptosporidiosis}

The development of future control methods against Cryptosporidium is likely to focus on vaccines and other immunotherapies. Therefore, there is an increased need to define the immunological parameters associated with disease progression. To date, most of the literature describing the immune response induced by Cryptosporidium parasites has been generated from studies in mice. Overall, the immune response to Cryptosporidium infection in humans and cattle is poorly understood. Studies in these clinically relevant hosts are urgently required in order to more effectively identify strategies to improve control of cryptosporidiosis. Here, we summarise our current understanding of the immune response to C. parvum infection (summarised in Figure 4).

\subsection{Innate immune response}

\subsubsection{Epithelial cells}

Intestinal epithelial cells represent the primary cellular target for Cryptosporidium infection in vivo. Pathogen recognition receptors (PRRs) are involved in the detection of molecular features of pathogens by the innate immune system (reviewed in [87]). Among the different families of PRRs, the toll-like receptors (TLRs) have been shown to be important during $C$. parvum infection of intestinal epithelial cells. In cattle, mRNA levels of TLR2 and TLR4 were increased following infection of bovine intestinal epithelial cells with C. parvum, whereas the expression of TLR1, TLR3 and TLR5-TLR10 were unchanged. Interactions between C. parvum and TLR2/ TLR4 expressed by bovine intestinal epithelial cells result in the activation of $\mathrm{NF \kappa B}$ and subsequently, production of TNF $\alpha$ and IL-8 [88]. Similarly, infection of human biliary epithelial cells (cholangiocytes) with $C$. parvum induced recruitment of TLR2 and TLR4 to the attachment site of infected epithelial cells [89] and infection of the human epithelial cell line HCT-8 with $C$. parvum has also been shown to induce the expression

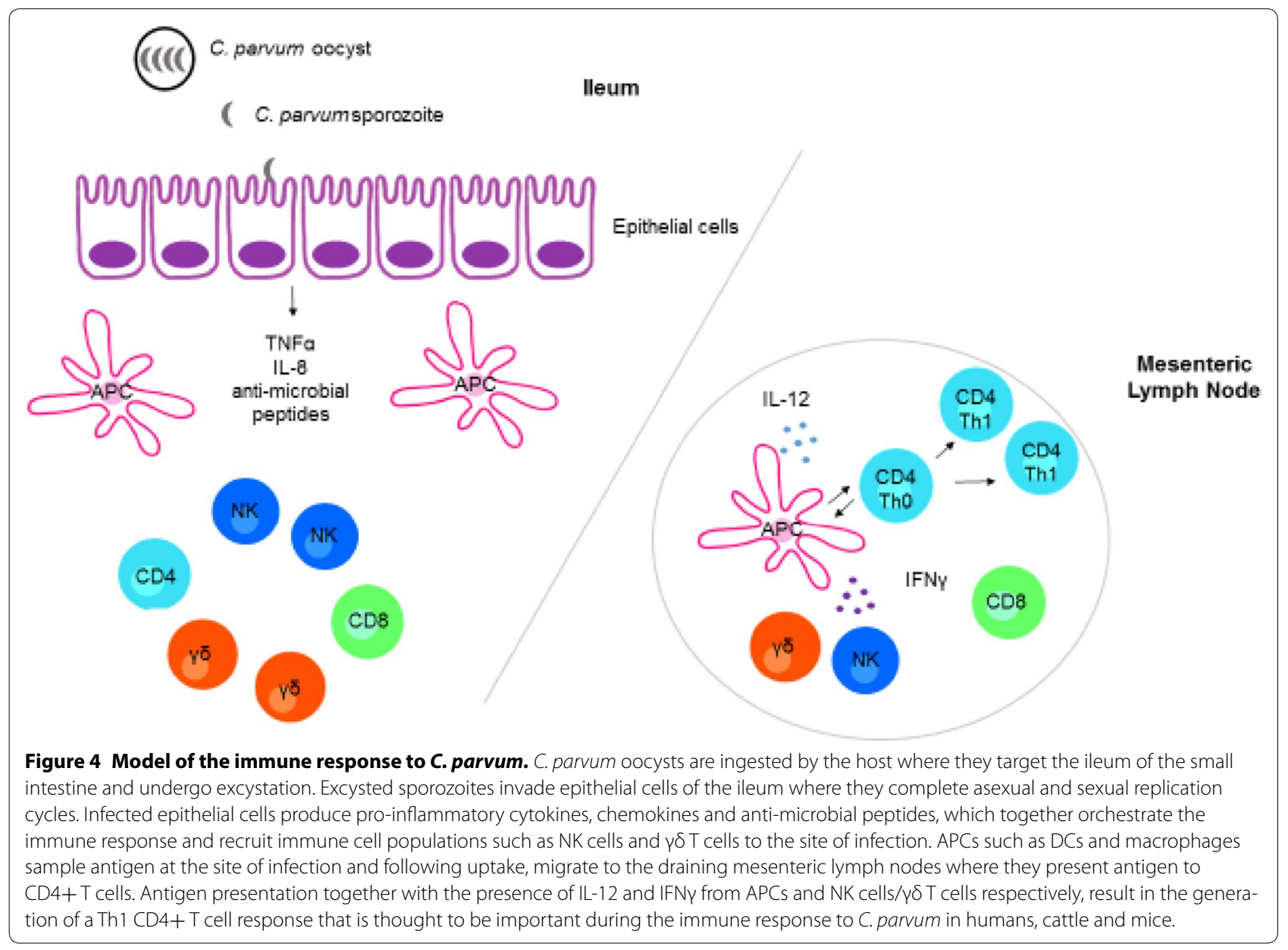


of the pro-inflammatory cytokine IL-18 [90]. In addition to production of pro-inflammatory cytokines and chemokines, bovine and human intestinal epithelial cells secrete antimicrobial peptides after invasion by Cryptosporidium. For example, mRNA levels of $\beta$-defensin were increased in the intestine of C. parvum-infected calves compared with control tissues [91]. The human epithelial cell lines HCT-8 and HT-29 secrete increased levels of LL-37 and $\alpha$-defensin-2 respectively after IL-18 stimulation, which could be a mechanism adopted by the host to limit Cryptosporidium [90]. As mentioned previously, C. parvum infection of human cholangiocytes attracted TLR2 and TLR4 to the cell surface, and inhibition of this TLR signalling resulted in their reduced expression of $\beta$-defensin 2 [89]. Taken together, these data suggest that TLR signalling through bovine and human epithelial cells during C. parvum infection results in the production of pro-inflammatory cytokines, chemokines and antimicrobial peptides. Whether these responses are important to induce a protective immune response to infection remains to be determined.

\subsubsection{Natural killer (NK) cells}

Natural killer cells (NK) are large granular lymphocytes, which were identified in the 1970s by their ability to lyse malignant or transformed cells without prior sensitisation [92]. This heterogeneous cell population has diverse roles in the immune system and NK cells are the first line of defence in the control of viruses, as well as certain intracellular bacteria and parasites [93-96]. Upon activation by the cytokines TNF $\alpha$, IFN $\alpha /$ IFN $\beta$, IL-12, IL-15 or IL-18 produced by accessory cell populations such as antigen presenting cells (APC), NK cells have two main effector functions. Firstly, NK cells are a significant source of immunoregulatory cytokines, primarily IFN $\gamma$ but also TNF $\alpha$, GM-CSF [97-99], IL-10 [98, 99] and IL-22 [100, 101]. Secondly, NK cells display cytotoxicity to target cells through the release of preformed, cytotoxic granules containing perforin and granulysin [102]. NK cells comprise $10-15 \%$ of peripheral blood lymphocytes in humans [102]. Within bovine peripheral blood, NK cells represent $0.5-10 \%$ of the total lymphocyte population with an increased prevalence in neonatal calves, particularly those aged between 8-120 days old. In parallel with humans and mice, the frequencies of circulating NK cells in bovine blood decline with age [103-105].

Natural killer cells exist as distinct subsets across species, for example, human NK cells are broadly subdivided based on their differential expression of the cell surface markers CD56 and CD16 (FcyRIII) [106, 107]. CD56 is not expressed in mice, therefore murine NK cells are distinguished by the expression of NK1.1 or CD49b [108] and can be further subdivided based on CD27 and
CD11b expression [109]. NKp46 (NCR1; CD335), a natural cytotoxicity receptor expressed exclusively by NK cells, has been used to identify bovine, ovine and porcine NK cells and is recognised as a pan-species marker of NK cells [110-113].

The role of NK cells during C. parvum infection has been studied in ovine, murine and human models of cryptosporidiosis. Within the first few days following infection of 1 day old lambs with C. parvum, the abundance of NKp46+ NK cells expressing CD16, CD25 and perforin was increased in the gut [114]. In mice, it was demonstrated that oocyst shedding was higher in C. parvum-infected Rag $2^{-/-} \gamma_{\mathrm{c}}^{-l-}$ mice (mice lacking $\mathrm{B}, \mathrm{T}$ and NK cells) compared with C. parvum-infected Rag2 $2^{-1-}$ mice (mice lacking $\mathrm{B}$ and $\mathrm{T}$ cells). Rag $2^{-/-} \gamma_{\mathrm{c}}^{-/-}$mice developed morbidity and died after C. parvum infection, but $\mathrm{Rag} 2^{-1-}$ mice remained healthy, thus highlighting a role for NK cells in reducing disease severity during murine C. parvum infection [115]. Although NK cells are an important source of IFN $\gamma, \operatorname{Rag} 2^{-/-} \gamma_{c}^{-l-}$ mice were able to produce IFN $\gamma$ despite their lack of NK cells, suggesting an alternative source of this cytokine during $C$. parvum infection [115].

Natural killer cells may also play a role in the clearance of $C$. parvum as human CD3- CD16+ CD56+ NK cells activated by IL- 15 were able to lyse $C$. parvum-infected epithelial cells in vitro. Lysis of epithelial cells was mediated by engagement of the NKG2D receptor expressed by NK cells, with ligands major histocompatibility complex (MHC) class I chain-related protein A (MICA) and B (MICB) on epithelial cells [116]. Therefore, NK cells may play a role in the early protective immune response to $C$. parvum infection in sheep, mice and humans, but their role in bovine cryptosporidiosis remains to be elucidated.

\subsection{3 $\gamma \delta T$ cells}

$\gamma \delta \mathrm{T}$ cells, which have a unique $\mathrm{T}$ cell receptor (TCR) consisting of one $\gamma$ chain and one $\delta$ chain, constitute a minor fraction $(5-10 \%)$ of the circulating lymphocyte population in humans and mice, but are more abundant in the gut mucosa. However, $\gamma \delta \mathrm{T}$ cells are a major subset of lymphocytes in ruminants and constitute up to $60 \%$ of circulating $\mathrm{T}$ cells in calves less than 6 months of age [117]. $\gamma \delta$ T cells are involved in antigen presentation, cytokine production and regulation of the immune response.

Following C. parvum infection of calves, there was a significant increase in the frequency of $\gamma \delta$ T cells in the ileum at day 3 post infection [118]. In a study comparing C. parvum infected-TCR $\alpha$ or TCR $\delta$ deficient mice, which lack $\alpha \beta \mathrm{T}$ cells and $\gamma \delta \mathrm{T}$ cells respectively, it was demonstrated that TCR $\alpha$ deficient mice were unable to clear the parasite whereas TCR $\delta$ deficient mice were able to clear 
C. parvum, albeit at a slower rate than wild type (control) mice. The authors concluded that $\gamma \delta \mathrm{T}$ cells are involved in the initial control of $C$. parvum infection in mice and $\alpha \beta \mathrm{T}$ cells are necessary for complete clearance of the parasite [119]. Thus, evidence suggests that $\gamma \delta \mathrm{T}$ cells may be involved in the early protective immune response to $C$. parvum in cattle and mice.

\subsubsection{Dendritic cells (DCs)}

Dendritic cells (DCs) are a heterogeneous population of potent APC that are essential mediators of immunity [120] and tolerance [121]. Stem cell precursors in the bone marrow give rise to circulating myeloid or lymphoid precursors that enter tissues and reside as immature DCs. Monocytes, macrophages and DCs share a common progenitor [122]. The cytokine Flt3L drives differentiation of these progenitor cells into DCs [123] and loss of Flt3L [124], Flt3 [125] or downstream signalling molecule STAT3 [126] reduces the number of DCs in vivo.

Dendritic cells are predominantly found underlying body surfaces including the skin, intestine and the trachea. They act as sentinels and respond to infection, inflammatory signals or tissue damage by migrating away from the periphery towards draining lymph nodes where they present antigen and initiate primary $\mathrm{T}$ cell mediated immune responses [127]. Two weeks after oral exposure of mice to C. parvum, live parasites were detected in the mesenteric lymph nodes and were associated with CD11c + DCs therefore suggesting DCs could take up C. parvum in vivo and migrate to the local lymph nodes [128]. During migration, DCs undergo maturation that is characterised by reduced endocytosis and an augmented expression of MHC molecules, costimulatory molecules and adhesion molecules. Following in vitro infection of mouse bone marrow-derived dendritic cells (BMDCs) with C. parvum sporozoites, DCs increased their expression of CD40, CD80 and CD86. In addition to augmented expression of these co-stimulatory molecules, BMDCs exposed to $C$. parvum produced pro-inflammatory cytokines including TNF $\alpha$, IL-6 and IL-12 [128]. Production of IL-12 by C. parvum-infected BMDCs from C3H/ HeJ mice (which lack a functional TLR4 pathway) was defective, suggesting that TLR4 signalling is important for production of IL-12 by C. parvum-infected BMDCs [128].

Interestingly, neonatal mice have a reduced number of intestinal CD103+ DCs due to a weak production of chemokines (CCL3, CCL4, CCL5, CCL22, CXCL9 and CXCL10) by intestinal epithelial cells, which results in an increased susceptibility to C. parvum infection. Injecting neonatal mice with Flt3L in vivo increased the number of CD103+ DCs and coincided with their improved resistance to infection [129]. Conversely, CD11c-DTR-Tg mice (depleted of CD11c+ DCs) have an increased susceptibility to infection with C. parvum. Adoptive transfer of DCs stimulated with live sporozoites reduced the parasite load therefore illustrating the importance of DCs as mediators of C. parvum infection in mice [130].

\subsubsection{Macrophages}

Macrophages are a diverse population of specialized phagocytic cells that are essential for host defense, homeostasis and wound repair. They are derived from bone marrow precursors and circulating blood monocytes, which differentiate into resident macrophages or DCs upon tissue entry [131]. Similar to DCs, the functions of macrophages include phagocytosis (they are known as the 'professional phagocytes'), antigen presentation and cytokine production.

$\operatorname{Rag} 2^{-1-} \gamma_{c}^{-1-}$ mice are able to produce IFN $\gamma$ despite their lack of NK cells, which suggested an alternative source of innate IFN $\gamma$ during C. parvum infection [115]. Further extension of this work demonstrated that depletion of macrophages, by treatment with clodronatecontaining liposomes, reduced resistance to C. parvum infection in mice. Importantly, mice depleted of macrophages were unable to produce IFN $\gamma$, indicating that macrophages were the alternative source of IFN $\gamma$ during C. parvum infection. In addition, the authors showed that IL-18 was an important factor for immunity to $C$. parvum in $\operatorname{Rag}^{-I-} \gamma_{\mathrm{c}}^{-/-}$mice and IL-18 promoted production of IFN $\gamma$ by macrophages during infection [132]. The inability of IFNY gene-knockout mice to control $C$. parvum infection was associated with reduced recruitment of macrophages and $\mathrm{T}$ cells to the lamina propria following infection suggesting they play an important role in control of infection in mice [133]. The role of macrophages in human and ruminant models of cryptosporidiosis is currently unknown.

\subsection{Adaptive immune response 4.2.1 CD4+ T cells}

Cell mediated immunity, particularly CD4+ $\mathrm{T}$ cells, is essential for the protective immune response to Cryptosporidium infection. This is highlighted by the increased susceptibility of acquired immune deficiency syndrome (AIDS) patients (who have low numbers of CD4+ T cells) to C. parvum infection [134], and ability of the parasite to cause chronic infections in MHC class II deficient mice (which lack functional CD4+ T cells) [135]. Importantly, cryptosporidiosis can be resolved in AIDS patients following restoration of their CD4+ T cell levels [135].

\subsubsection{Th1 immune responses}

A major function of CD4+ T cells is to act as helper lymphocytes, and upon interaction with antigen presenting 
cells, naïve CD4+ $\mathrm{T}$ cells can differentiate into various helper cell subsets. Differentiation of naïve CD4+ T cells, is dictated in part, by the cytokine milieu present at the time of differentiation. For example, the presence of IL-12 and IFN $\gamma$ in the local environment results in the development of a Th1 immune response which is characterised by the production of TNF $\alpha$, IL-2 and IFN $\gamma$ [136]. Th1 biased immune responses are important for protection against intracellular pathogens and are involved during Cryptosporidium infection. In bovine studies, stimulation of PBMCs from C. parvum-infected calves with antigen derived from C. parvum oocysts resulted in an increased production of IFNy by CD4+ T cells [137]. PBMCs from neonatal calves experimentally infected with $C$. parvum had increased mRNA levels of the Th1 cytokines from day 3 post-infection [138]. Similarly, expression of IL-12p40 and IFN $\gamma$ by lamina propria and intraepithelial lymphocytes were noted following $C$. parvum infection of neonatal calves [139]. Similarly, a case of severe cryptosporidiosis was reported in a patient with an IFN $\gamma$ deficiency [140] and IFN $\gamma$ gene-knockout mice are highly susceptible to infection [141]. Treatment of immunocompetent or immunodeficient mice with exogenous IL-12 prior to infection with $C$. parvum reduced the severity of infection in an IFN $\gamma$ dependent manner [142]. However, in a study comparing Rag2 $2^{-/-}$and wild type neonatal mice, it was demonstrated that CD4+ T cells were not required for control of C. parvum infection [143].

Taken together, these studies highlight the importance of Th1 polarised CD4+ $\mathrm{T}$ cell responses during C. par$v u m$ infection of cattle, humans and mice.

\subsubsection{Th2 immune responses}

Th2 polarisation of the immune response is driven by the presence of an IL-4 rich cytokine milieu which induces the differentiation of naïve $\mathrm{CD} 4+\mathrm{T}$ cells into the Th2 subset of CD4+ $\mathrm{T}$ cells, characterised by their production of IL-4, IL-5, IL-10 and IL-13. Th2 responses are important in defence against extracellular pathogens, allergy/asthma and antibody mediated immunity [144].

Treatment of C57BL/6 mice with anti-IL-4 monoclonal antibody prior to infection with $C$. parvum caused prolonged excretion of $C$. parvum oocysts for at least 11 days longer than control mice. Furthermore, IL-4 deficient mice also exhibited prolonged excretion of $C$. parvum oocysts, which lasted 23 days longer than mice with intact IL-4 [145]. Interestingly, in a study using IL-4 deficient mice, IL-4R $\alpha$ deficient mice and IL-4 neutralising antibody, it was demonstrated that production of IL-4 during C. parvum infection of BALB/c mice induced expression of IFN $\gamma$ and IL-12 and therefore promoted Th1 immunity in the intestine [146]. Thus, production of the Th2 cytokine IL-4 in response to murine C. parvum infection may drive protective Th1 immune responses.

\subsubsection{Th17 immune responses}

A third subset of CD4+ T cells, distinct from Th1 and Th2 CD4+ T cells, was described in 2005 and named the Th17 subset of CD4+ T cells [147]. The presence of TGF $\beta$, IL-6 and IL-23 in the local environment results in differentiation of Th17 cells which are characterised by the production of IL-17 (also known as IL-17A). Th17 CD4 $+\mathrm{T}$ cells are important in host defence against a wide range of pathogens, for example, through recruitment of macrophages and neutrophils to the site of infection [148]. In mice immunosuppressed by dexamethasone and then infected with $C$. parvum, it was shown that mRNA levels of TGF- $\beta$ and IL- 6 in the gut associated lymphoid tissue (GALT) increased at 6 and $12 \mathrm{~h}$ post-infection respectively. This was alongside increased levels of STAT-3 and the transcription factor ROR $\gamma \mathrm{T}$, which promote differentiation of naïve CD4+ T cells into Th17 cells. Consequently, levels of IL-17 protein increased in the GALT after infection [149]. There is little known about the possible role of Th17 immune response during the bovine immune response to $C$. parvum infection.

\subsubsection{CD8 + T cells}

CD8 $+\mathrm{T}$ cells, alongside CD4 $+\mathrm{T}$ cells and $\gamma \delta \mathrm{T}$ cells, are present at an increased frequency within the ileum of $C$. parvum-infected calves at day 3 post-infection, compared with tissues from uninfected calves [118]. Furthermore, following infection of 1 day old lambs with $C$. parvum, CD8+/NKp46- lymphocytes (which the authors concluded were most likely to be CD8+ T cells) were significantly increased in the small intestine at day 3 and day 6 post infection, reflecting their recruitment following infection [114]. Therefore, CD8+ $\mathrm{T}$ cells appear to be involved in the immune response after infection of calves and lambs with $C$. parvum. Conversely, in studies using MHC class I deficient mice, which lack CD8+ T cells, it was shown that mice were not susceptible to $C$. parvum infection whereas mice which lacked $\mathrm{CD} 4+\mathrm{T}$ cells due to a MHC class II deficiency were highly susceptible to infection. Thus it appears that CD4 $+\mathrm{T}$ cells, rather than CD8+ T cells, are important during murine C. parvum infection [150].

\subsubsection{B cells}

The relevance of $\mathrm{B}$ cells and immunoglobulins during Cryptosporidium infection remains controversial. Mice depleted of $B$ cells (and therefore unable to produce appropriate levels of protective antibody) were able to control C. parvum infection to a similar level as mice 
with intact B cells [151]. Using gene-targeted B cell deficient mice, it has also been shown that B cells were not required for resistance to initial $C$. parvum infection or resolution of infection [152]. Data from these studies suggest that $B$ cells and antibody-mediated immune responses may not be necessary for protection against murine C. parvum infection. Whether the same is true for protection against Cryptosporidium infection in natural host species remains to be determined.

\subsubsection{Models to study the interaction between Cryptosporidium and the host}

Generally, mice infected with $C$. parvum have limitations when used as models for Cryptosporidium infection in humans or cattle. Additionally, bovine-specific examples such as the significantly increased frequency of nonconventional $\mathrm{T}$ cells, ultralong complementarity-determining region 3 (CDR3) domain antibodies and uniquely expanded NK receptor repertoires [153-155] illustrate the many fundamental differences between the murine and bovine immune systems. The impact that these factors may play during Cryptosporidium infection cannot be captured using mouse models. Improved in vitro models would also ideally be developed in order to enable the study of the interaction between C. parvum and the host. To date, epithelial cell lines (particularly the HCT-8 cell line) have been utilised to decipher the interaction between the parasite and human intestinal epithelial cells. Whilst these studies are valuable, epithelial cell lines are not fully representative of the complex structure and cellular diversity of the intestinal epithelium, which consists of many cell types including epithelial cells, goblet cells, stem cells, Paneth cells and enteroendocrine cells. Intestinal organoids, or 'mini guts', appear to represent an example of a physiologically-relevant in vitro system that has the potential to fill this important requirement gap. These are three dimensional structures, differentiated in vitro from intestinal stem cells, which recapitulate the structure of the intestinal epithelium in vivo and contain all of the cell types associated with the intestine. Organoids would be excellent tools to study the early interactions of Cryptosporidium with the gut epithelium, as pathogens can be introduced into the lumen of the intestinal organoids in vitro enabling their relationship with the host to be deciphered in a physiologically relevant context. Zhang et al. provided the first study of C. parvum and intestinal organoids, which were derived from mouse tissue. The authors illustrated that the presence of C. parvum attenuated the differentiation of murine intestinal organoids [156]. Therefore, similar in vitro systems would be advantageous to understand the nature of the host-pathogen interaction during C. parvum infection in cattle, and other relevant host species.

\section{Concluding remarks}

Despite being discovered over 100 years ago Cryptosporidium remains one of the most difficult pathogens to control on farms and in the environment. To date, progress in the development of effective treatments for humans or animals has been slow. This may be due, in part, to the lack of understanding of the cellular and molecular interactions that occur in the gut mucosa during the early stage interactions between host and parasite. The majority of studies that have been carried out have focussed on mice, an asymptomatic model. Therefore, a more in-depth understanding of the pathogenesis of Cryptosporidium infection in clinically relevant hosts is urgently required. Data derived from these studies is necessary to help identify the factors that influence disease resistance and recovery, and to aid the development of effective control strategies to help control this important disease.

\section{Abbreviations}

$\%$ : percent; : approximately; $<$ : less than; $=$ : equal to; >: more than; ${ }^{\circ} \mathrm{C}$ : degrees centigrade; AIDS: acquired immune deficiency syndrome; APC: antigen presenting cell; BMDCs: bone marrow-derived dendritic cells; $C$. andersoni: Cryptosporidium andersoni; C. bovis: Cryptosporidium bovis; C. hominis: Cryptosporidium hominis; C. meleagridis: Cryptosporidium meleagridis; C. parvum: Cryptosporidium parvum; C. ryanae: Cryptosporidium ryanae; CD: cluster of differentiation; CDR: complementarity-determining region; $\mathrm{cm}$ : centimetre; DCs: dendritic cells; DNA: deoxyriboneucleic acid; GALT: gut associated lymphoid tissue; GM-CSF: granulocyte-macrophage colony-stimulating factor; HCT-8: human colon carcinoma cell line; HPA: health protection agency; HPS: health protection Scotland; HT-29: human colon adenocarcinoma cell line; ID50: infectious dose to $50 \%$ of exposed individuals; IFN: interferon; L: interleukin; kg: kilogram; MHC: major histocompatibility complex; MICA: MHC class I chainrelated protein A; MICB: MHC class I chain-related protein B; mRNA: messenger RNA; NFKB: nuclear factor kappa-light-chain-enhancer of activated B cells; NK: natural killer cells; NKG2D: natural killer group 2 member D; PBMCs: peripheral blood mononuclear cells; PCR: polymerase chain reaction; $\mathrm{pH}$ : negative log of the activity of the hydrogen ion in an aqueous solution; PRRs: pathogen recognition receptors; Rag2: recombination activating gene 2; RFLP: restriction fragment length polymorphism; RORyt: retinoid-related orphan receptor gamma t; spp.: species; STAT3: signal transducer and activator of transcription 3; TCR: T cell receptor; TGF: transforming growth factor; Th: Thelper; TLR: tolllike receptors; TNF: tumor necrosis factor; UK: United Kingdom; USA: United States of America; VIDA: veterinary investigation diagnosis analysis; $a$ : alpha; $\beta$ : beta; $\uparrow:$ gamma; $\delta$ : delta.

\section{Competing interests}

The authors declare that they have no competing interests.

\section{Authors' contributions}

$\mathrm{CH}$ and ST prepared the original draft of the manuscript. All authors provided additional input for the manuscript. All authors read and approved the final manuscript.

\section{Acknowledgements}

The images in Figure 3 were used with the kind permission of Saul Tzipori.

\section{Author details}

${ }^{1}$ Moredun Research Institute, Pentlands Science Park, Bush Loan, Edinburgh EH26 OPZ, Scotland, UK. ${ }^{2}$ The Roslin Institute \& Royal (Dick) School of Veterinary Sciences, University of Edinburgh, Easter Bush, Midlothian EH25 9RG, UK. 
Availability of data and materials

Not applicable.

\section{Consent for publication}

Not applicable.

\section{Ethics approval and consent to participate}

Not applicable.

\section{Funding}

This work was supported by the Animal Health Research Club ARC (Grant: BB/MO12751/1), and the Scottish Government (RESAS). LM is supported by a Royal Society University Research Fellowship (UF140610). CH, LM, JH and NAM were also supported by Institute Strategic Programme Grant funding from the BBSRC (BB/J004227/1).

\section{Publisher's Note}

Springer Nature remains neutral with regard to jurisdictional claims in published maps and institutional affiliations.

Received: 20 February 2017 Accepted: 1 August 2017

Published online: 11 August 2017

\section{References}

1. Tyzzer EE (1912) Cryptosporidium parvum (sp. nov.), a coccidium found in the small intestine of the common mouse. Arch fur Protistenkunde 26:394-418

2. Chalmers RM, Katzer F (2013) Looking for Cryptosporidium: the application of advances in detection and diagnosis. Trends Parasitol 29:237-251

3. Panciera RJ, Thomassen RW, Garner FM (1971) Cryptosporidial infection in a calf. Vet Pathol 8:479-484

4. Tzipori S, Smith M, Halpin C, Angus KW, Sherwood D, Campbell I (1983) Experimental cryptosporidiosis in calves: clinical manifestations and pathological findings. Vet Rec 112:116-120

5. Cho Yl, Yoon KJ (2014) An overview of calf diarrhea-infectious etiology, diagnosis, and intervention. J Vet Sci 15:1-17

6. Blanchard PC (2012) Diagnostics of dairy and beef cattle diarrhea. Vet Clin North Am Food Anim Pract 28:443-464

7. Mosier DA, Oberst RD (2000) Cryptosporidiosis: a global challenge. Ann NY Acad Sci 916:102-111

8. APHA, SRUC, Veterinary investigation diagnosis analysis (VIDA) report (2014) https://www.gov.uk/government/publications/ veterinary-investigation-diagnosis-analysis-vida-report-2014

9. Centres for disease control and prevention (2015) https://phil.cdc.gov/ phil/details.asp. Accessed 19 May 2015

10. Cacciò S, Widmer G, (2014) Cryptosporidium: parasite and disease, (Ed.) Springer-Verlag, Wien XI:564. http://www.springer.com/gp/ book/9783709115619

11. Fujino T, Matsui T, Kobayashi F, Haruki K, Yoshino Y, Kajima J, Tsuji M (2002) The effect of heating against Cryptosporidium oocysts. J Vet Med Sci 64:199-200

12. Fayer R, Trout J, Nerad T (1996) Effects of a wide range of temperatures on infectivity of Cryptosporidium parvum oocysts. J Eukaryot Microbiol 43:64S

13. Robertson LJ, Campbell AT, Smith HV (1992) Survival of Cryptosporidium parvum oocysts under various environmental pressures. Appl Environ Microbiol 58:3494-3500

14. Fayer R, Santín M, Xiao L (2005) Cryptosporidium bovis n. sp. (Apicomplexa: Cryptosporidiidae) in cattle (Bos taurus). J Parasitol 91:624-629

15. Fayer R, Santín M, Trout JM (2008) Cryptosporidium ryanae n. sp. (Apicomplexa: Cryptosporidiidae) in cattle (Bos taurus). Vet Parasitol 156:191-198

16. Santín M, Trout JM, Xiao L, Zhou L, Greiner E, Fayer R (2004) Prevalence and age-related variation of Cryptosporidium species and genotypes in dairy calves. Vet Parasitol 122:103-117
17. Silverlås C, Bosaeus-Reineck H, Näslund K, Björkman C (2013) Is there a need for improved Cryptosporidium diagnostics in Swedish calves? Int J Parasitol 43:155-161

18. Lindsay DS, Upton SJ, Owens DS, Morgan UM, Mead JR, Blagburn BL (2000) Cryptosporidium andersoni n. sp. (Apicomplexa: Cryptosporiidae) from cattle, Bos taurus. J Eukaryot Microbiol 47:91-95

19. Ralston B, Thompson RC, Pethick D, McAllister TA, Olson ME (2010) Cryptosporidium andersoni in western Australian feedlot cattle. Aust Vet J 88:458-460

20. Kvác M, Hanzlíková D, Sak B, Kvetonová D (2009) Prevalence and agerelated infection of Cryptosporidium suis, C. muris and Cryptosporidium pig genotype II in pigs on a farm complex in the Czech Republic. Vet Parasitol 160:319-322

21. Kvác M, Nemejc K, Kestranová M, Kvetonová D, Wagnerová P, Kotková M, Rost M, Samková E, McEvoy J, Sak B (2014) Age related susceptibility of pigs to Cryptosporidium scrofarum infection. Vet Parasito 202:330-334

22. Zambriski JA, Nydam DV, Bowman DD, Bellosa ML, Burton AJ, Linden TC, Liotta JL, Ollivett TL, Tondello-Martins L, Mohammed HO (2013) Description of fecal shedding of Cryptosporidium parvum oocysts in experimentally challenged dairy calves. Parasitol Res 112:1247-1254

23. Nydam DV, Wade SE, Schaaf SL, Mohammed HO (2001) Number of Cryptosporidium parvum oocysts or Giardia spp cysts shed by dairy calves after natural infection. Am J Vet Res 62:1612-1615

24. Okhuysen PC, Chappell CL, Crabb JH, Sterling CR, DuPont HL (1999) Virulence of three distinct Cryptosporidium parvum isolates for healthy adults. J Infect Dis 180:1275-1281

25. Zambriski JA, Nydam DV, Wilcox ZJ, Bowman DD, Mohammed HO, Liotta JL (2013) Cryptosporidium parvum: determination of $\mathrm{ID}_{50}$ and the doseresponse relationship in experimentally challenged dairy calves. Vet Parasitol 197:104-112

26. Featherstone CA, Giles M, Marshall JA, Mawhinney IC, Holliman A, Pritchard GC (2010) Cryptosporidium species in calves submitted for postmortem examination in England and Wales. Vet Rec 167:979-980

27. Fayer R, Santín M, Trout JM, Greiner E (2006) Prevalence of species and genotypes of Cryptosporidium found in 1-2-year-old dairy cattle in the eastern United States. Vet Parasitol 135:105-112

28. Brook E, Hart CA, French N, Christley R (2008) Prevalence and risk factors for Cryptosporidium spp. infection in young calves. Vet Parasitol 152:46-52

29. Joachim A, Krull T, Schwarzkopf J, Daugschies A (2003) Prevalence and control of bovine cryptosporidiosis in German dairy herds. Vet Parasitol 112:277-288

30. Wells B, Shaw H, Hotchkiss E, Gilray J, Ayton R, Green J, Katzer F, Wells A, Innes E (2015) Prevalence, species identification and genotyping Cryptosporidium from livestock and deer in a catchment in the Cairngorms with a history of a contaminated public water supply. Parasites Vectors 8:66

31. Smith RP, Clifton-Hadley FA, Cheney T, Giles M (2014) Prevalence and molecular typing of Cryptosporidium in dairy cattle in England and Wales and examination of potential on-farm transmission routes. Vet Parasitol 204:111-119

32. Imre K, Lobo LM, Matos O, Popescu C, Genchi C, Darabus G (2011) Molecular characterisation of Cryptosporidium isolates from preweaned calves in Romania: is there an actual risk of zoonotic infections? Vet Parasitol 181:321-324

33. Broglia A, Reckinger S, Cacció SM, Nockler K (2008) Distribution of Cryptosporidium parvum subtypes in calves in Germany. Vet Parasitol 154:8-13

34. Rieux A, Paraud C, Pors I, Chartier C (2013) Molecular characterization of Cryptosporidium isolates from pre-weaned calves in western France in relation to age. Vet Parasitol 197:7-12

35. Santín M, Trout JM, Fayer R (2008) A longitudinal study of cryptosporidiosis in dairy cattle from birth to 2 years of age. Vet Parasitol 155:15-23

36. Duranti A, Cacció SM, Pozio E, Di Egidio A, De Curtis M, Battisti A, Scaramozzino P (2009) Risk factors associated with Cryptosporidium parvum infection in cattle. Zoonoses Public Health 56:176-182

37. Bendali F, Bichet H, Schelcher F, Sanaa M (1999) Pattern of diarrhoea in newborn beef calves in South-west France. Vet Res 30:61-74 
38. Peng MM, Wilson ML, Holland RE, Meshnick SR, Lal AA, Xiao L (2003) Genetic diversity of Cryptosporidium spp. in cattle in Michigan: implications for understanding the transmission dynamics. Parasitol Res 90:175-180

39. Thomson S, Innes EA, Jonsson NN, Katzer F (2016) A multiplex PCR test to identify four common cattle-adapted Cryptosporidium species. Parasitol Open 2:9

40. Hadfield SJ, Robinson G, Elwin K, Chalmers RM (2011) Detection and differentiation of Cryptosporidium spp. in human clinical samples by use of real-time PCR. J Clin Microbiol 49:918-924

41. Wells B, Thomson S, Ensor H, Innes EA, Katzer F (2016) Development of a sensitive method to extract and detect low numbers of Cryptosporidium oocysts from adult cattle faecal samples. Vet Parasitol 227:26-29

42. Bukhari Z, Smith HV (1995) Effect of three concentration techniques on viability of Cryptosporidium parvum oocysts recovered from bovine feces. J Clin Microbiol 33:2592-2595

43. Gunn GJ, Stott AW, A comparison of economic losses due to calf enteritis and calf pneumonia in Scottish beef herds, XX World Buiatrics Congress 1998. http://www.sciquest.org.nz/node/62142

44. Ajjampur SS, Sarkar R, Sankaran P, Kannan A, Menon VK, Muliyil J, Ward H, Kang G (2010) Symptomatic and asymptomatic Cryptosporidium infections in children in a semi-urban slum community in southern India. Am J Trop Hyg 83:1110-1115

45. Checkley W, Epstein LD, Gilman RH, Black RE, Cabrera L, Sterling CR (1998) Effects of Cryptosporidium parvum infection in Peruvian children: growth faltering and subsequent catch-up growth. Am J Epidemiol 148:497-506

46. Sweeny JP, Ryan UM, Robertson ID, Jacobson C (2011) Cryptosporidium and Giardia associated with reduced lamb carcase productivity. Vet Parasitol 182:127-139

47. Lacroix S, Mancassola R, Naciri M, Laurent F (2001) Cryptosporidium parvum-specific mucosal immune response in C57BL/6 neonatal and gamma interferon-deficient mice: role of tumor necrosis factor alpha in protection. Infect Immun 69:1635-1642

48. Jacobson C, Williams A, Yang R, Ryan U, Carmichael I, Campbell AJ, Gardner GE (2016) Greater intensity and frequency of Cryptosporidium and Giardia oocyst shedding beyond the neonatal period is associated with reductions in growth, carcase weight and dressing efficiency in sheep. Vet Parasitol 228:42-51

49. Chalmers RM, Giles M (2010) Zoonotic cryptosporidiosis in the UKchallenges for control. J Appl Microbiol 109:1487-1497

50. Chalmers RM, Smith R, Elwin K, Clifton-Hadley FA, Giles M (2011) Epidemiology of anthroponotic and zoonotic human cryptosporidiosis in England and Wales, 2004-2006. Epidemiol Infect 139:700-712

51. Checkley W, White AC Jr, Jaganath D, Arrowood MJ, Chalmers RM, Chen XM, Fayer R, Griffiths JK, Guerrant RL, Hedstrom L, Huston CD, Kotloff KL, Kang G, Mead JR, Miller M, Petri WA Jr, Priest JW, Roos DS, Striepen B, Thompson RC, Ward HD, Van Voorhis WA, Xiao L, Zhu G, Houpt ER (2015) A review of the global burden, novel diagnostics, therapeutics, and vaccine targets for Cryptosporidium. Lancet Infect Dis 15:85-94

52. Shirley DA, Moonah SN, Kotloff KL (2012) Burden of disease from cryptosporidiosis. Curr Opin Infect Dis 25:555-563

53. Chalmers RM, Davies AP (2010) Minireview: clinical cryptosporidiosis. Exp Parasitol 124:138-146

54. Tzipori S (2002) Introduction. Cryptosporidiosis: current trends and challenges. Microbes Infect 4:1045

55. Kotloff KL, Nataro JP, Blackwelder WC, Narsin D, Farag TH, Panchalingham S, Wu Y, Sow SO, Sur D, Breiman RF et al (2013) Burden and aetiology of diarrhoeal disease in infants and young children in developing countries (the Global Enteric Multicenter Study, GEMS): a prospective, case-control study. Lancet 382:209-211

56. Striepen B (2013) Parasitic infections: time to tackle cryptosporidiosis. Nature 503:189-191

57. Liu L, Johnson HL, Cousens S, Perin J, Scott S, Lawn JE, Rudan I, Campbell H, Cibulskis R, Li M, Mathers C, Black RE, Child Health Epidemiology Reference Group of WHO and UNICEF (2012) Global, regional, and national causes of child mortality: an updated systematic analysis for 2010 with time trends since 2000. Lancet 379:2151-2156

58. Chalmers RM, Elwin K, Thomas AL, Guy EC, Mason B (2009) Long-term Cryptosporidium typing reveals the aetiology and species-specific epidemiology of human cryptosporidiosis in England and Wales, 2000 to 2003. Euro Surveill 14(2):785-794
59. Strachan NJ, Ogden ID, Smith-Palmer A, Jones K (2003) Foot and mouth epidemic reduces cases of human cryptosporidiosis in Scotland. J Infect Dis 188:783-786

60. Hunter PR, Chalmers RM, Syed Q, Hughes LS, Woodhouse S, Swift L (2003) Foot and mouth disease and cryptosporidiosis: possible interaction between two emerging infectious diseases. Emerg Infect Dis 9:109-112

61. Gait R, Soutar RH, Hanson M, Fraser C, Chalmers R (2008) Outbreak of cryptosporidiosis among veterinary students. Vet Rec 162:843-845

62. Anderson BC, Donndelinger T, Wilkins RM, Smith J (1982) Cryptosporidiosis in a veterinary student. J Am Vet Med Assoc 180:408-409

63. Pohjola S, Oksanen H, Jokipii L, Jokipii AM (1986) Outbreak of cryptosporidiosis among veterinary students. Scand J Infect Dis 18:173-178

64. Preiser G, Preiser L, Madeo L (2003) An outbreak of cryptosporidiosis among veterinary science students who work with calves. J Am Coll Health 51:213-215

65. Gormley FJ, Little CL, Chalmers RM, Rawal N, Adak GK (2011) Zoonotic cryptosporidiosis from petting farms, England and Wales, 1992-2009. Emerg Infect Dis 17:151-152

66. Pritchard GC, Fleetwood AJ (1995) Cryptosporidiosis and farm visits. Vet Rec 136:179

67. Health protection report (2016) Public Health England, vol 10. https://www.gov.uk/government/publications/ health-protection-report-volume-10-2016

68. Casemore DP, Watkins J (1998) Review of disinfection and associated studies on Cryptosporidium, 1-56. http://dwi.defra.gov.uk/research/ completed-research/reports/dwi0805.pdf

69. Meganck V, Hoflack G, Opsomer G (2014) Advances in prevention and therapy of neonatal dairy calf diarrhoea: a systematical review with emphasis on colostrum management and fluid therapy. Acta Vet Scand 56:75

70. Harp JA, Goff JP (1998) Strategies for the control of Cryptosporidium parvum infection in calves. J Dairy Sci 81:289-294

71. Naciri M, Mancassola R, Yvoré P, Peeters JE (1993) The effect of halofuginone lactate on experimental Cryptosporidium parvum infections in calves. Vet Parasitol 45:199-207

72. Jarvie BD, Trotz-Williams LA, McKnight DR, Leslie KE, Wallace MM, Todd CG, Sharpe PH, Peregrine AS (2005) Effect of halofuginone lactate on the occurrence of Cryptosporidium parvum and growth of neonatal dairy calves. J Dairy Sci 88:1801-1806

73. Lefay D, Naciri M, Poirier P, Chermette R (2001) Efficacy of halofuginone lactate in the prevention of cryptosporidiosis in suckling calves. Vet Rec 148:108-112

74. Trotz-Williams LA, Jarvie BD, Peregrine AS, Duffield TF, Leslie KE (2011) Efficacy of halofuginone lactate in the prevention of cryptosporidiosis in dairy calves. Vet Rec 168:509

75. Fayer R, Ellis W (1993) Paromomycin is effective as prophylaxis for cryptosporidiosis in dairy calves. J Parasitol 79:771-774

76. Viu M, Quílez J, Sánchez-Acedo C, del Cacho E, López-Bernad F (2000) Field trial on the therapeutic efficacy of paromomycin on natural Cryptosporidium parvum infections in lambs. Vet Parasitol 90:163-170

77. Grinberg A, Markovics A, Galindez J, Lopez-Villalobos N, Kosak A, Tranquillo VM (2002) Controlling the onset of natural cryptosporidiosis in calves with paromomycin sulphate. Vet Rec 151:606-608

78. Moore DA, Atwill ER, Kirk JH, Brahmbhatt D, Herrera Alonso L, Hou $L$, Singer MD, Miller TD (2003) Prophylactic use of decoquinate for infections with Cryptosporidium parvum in experimentally challenged neonatal calves. J Am Vet Med Assoc 223:839-845

79. Ollivett TL, Nydam DV, Bowman DD, Zambriski JA, Bellosa ML, Linden TC, Divers TJ (2009) Effect of nitazoxanide on cryptosporidiosis in experimentally infected neonatal dairy calves. J Dairy Sci 92:1643-1648

80. Lendner M, Böttcher D, Delling C, Ojo KK, Van Voorhis WC, Daugschies A (2015) A novel CDPK1 inhibitor - a potential treatment for cryptosporidiosis in calves? Parasitol Res 114:335-336

81. Schaefer DA, Betzer DP, Smith KD, Millman ZG, Michalski HC, Menchaca SE, Zambriski JA, Ojo KK, Hulverson MA, Arnold SL, Rivas KL, Vidadala RS, Huang W, Barrett LK, Maly DJ, Fan E, Van Voorhis WC, Riggs MW (2016) Novel bumped kinase inhibitors are safe and effective therapeutics in the calf clinical model for cryptosporidiosis. J Infect Dis 214:1856-1864

82. Harp JA, Goff JP (1995) Protection of calves with a vaccine against Cryptosporidium parvum. J Parasitol 81:54-57 
83. Jenkins M, Higgins J, Kniel K, Trout J, Fayer R (2004) Protection of calves against cryptosporiosis by oral inoculation with gamma-irradiated Cryptosporidium parvum oocysts. J Parasitol 90:1178-1180

84. Harp JA, Jardon P, Atwill ER, Zylstra M, Checel S, Goff JP, De SC (1996) Field testing of prophylactic measures against Cryptosporidium parvum infection in calves in a California dairy herd. Am J Vet Res 57:1586-1588

85. Innes EA, Bartley PM, Rocchi M, Benavidas-Silvan J, Burrells A, Hotchkiss E, Chianini F, Canton G, Katzer F (2011) Developing vaccines to control protozoan parasites in ruminants: dead or alive? Vet Parasitol 180:155-163

86. Perryman LE, Kapil SJ, Jones ML, Hunt EL (1999) Protection of calves against cryptosporidiosis with immune bovine colostrum induced by a Cryptosporidium parvum recombinant protein. Vaccine 17:2142-2149

87. Akira S, Uematsu S, Takeuchi O (2006) Pathogen recognition and innate immunity. Cell 124:783-801

88. Yang Z, Fu Y, Gong P, Zheng J, Liu L, Yu Y, Li J, Li H, Yang J, Zhang X (2015) Bovine TLR2 and TLR4 mediate Cryptosporidium parvum recognition in bovine intestinal epithelial cells. Microb Pathog 85:29-34

89. Chen XM, O'Hara SP, Nelson JB, Splinter PL, Small AJ, Tietz PS, Limper AH, LaRusso NF (2005) Multiple TLRs are expressed in human cholangiocytes and mediate host epithelial defense responses to Cryptosporidium parvum via activation of NF-kappaB. J Immunol 175:7447-7456

90. McDonald V, Pollok RC, Dhaliwal W, Naik S, Farthing MJ, Bajaj-Elliott M (2006) A potential role for interleukin-18 in inhibition of the development of Cryptosporidium parvum. Clin Exp Immunol 145:555-562

91. Tarver AP, Clark DP, Diamond G, Russell JP, Erdjument-Bromage H, Tempst P, Cohen KS, Jones DE, Sweeney RW, Wines M, Hwang S, Bevins $C L$ (1998) Enteric beta-defensin: molecular cloning and characterization of a gene with inducible intestinal epithelial cell expression associated with Cryptosporidium parvum infection. Infect Immun 66:1045-1056

92. Kiessling R, Klein E, Pross H, Wigzell H (1975) "Natural" killer cells in the mouse. II. Cytotoxic cells with specificity for mouse Moloney leukemia cells. Characteristics of the killer cell. Eur J Immunol 5:117-121

93. Junqueira-Kipnis AP, Kipnis A, Jamieson A, Juarrero MG, Diefenbach A, Raulet DH, Turner J, Orme IM (2003) NK cells respond to pulmonary infection with Mycobacterium tuberculosis, but play a minimal role in protection. J Immunol 171:6039-6045

94. Cerwenka A, Lanier LL (2001) Natural killer cells, viruses and cancer. Nat Rev Immunol 1:41-49

95. Lieke T, Graefe SE, Klauenberg U, Fleischer B, Jacobs T (2004) NK cells contribute to the control of Trypanosoma cruzi infection by killing free parasites by perforin-independent mechanisms. Infect Immun 72:6817-6825

96. Artavanis-Tsakonas K, Riley EM (2002) Innate immune response to malaria: rapid induction of IFN-gamma from human NK cells by live Plasmodium falciparum-infected erythrocytes. J Immunol 169:2956-2963

97. Fehniger TA, Carson WE, Caligiuri MA (1999) Costimulation of human natural killer cells is required for interferon gamma production. Transplant Proc 31:1476-1478

98. Cooper MA, Fehniger TA, Turner SC, Chen KS, Ghaheri BA, Ghayur T, Carson WE, Caligiuri MA (2001) Human natural killer cells: a unique innate immunoregulatory role for the CD56(bright) subset. Blood 97:3146-3151

99. Boysen P, Olsen I, Berg I, Kulberg S, Johansen GM, Storset AK (2006) Bovine CD2-/NKp46+ cells are fully functional natural killer cells with a high activation status. BMC Immunol 7:10

100. Cella M, Fuchs A, Vermi W, Facchetti F, Otero K, Lennerz JK, Doherty JM, Mills JC, Colonna M (2009) A human natural killer cell subset provides an innate source of IL-22 for mucosal immunity. Nature 457:722-725

101. Dhiman R, Indramohan M, Barnes PF, Nayak RC, Paidipally P, Rao LV, Vankayalapati R (2009) IL-22 produced by human NK cells inhibits growth of Mycobacterium tuberculosis by enhancing phagolysosomal fusion. J Immunol 183:6639-6645

102. Trinchieri G (1989) Biology of natural killer cells. Adv Immunol 47:187-376

103. Kulberg S, Boysen P, Storset AK (2004) Reference values for relative numbers of natural killer cells in cattle blood. Dev Comp Immunol 28:941-948

104. Graham EM, Thom ML, Howard CJ, Boysen P, Storset AK, Sopp P, Hope JC (2009) Natural killer cell number and phenotype in bovine peripheral blood is influenced by age. Vet Immunol Immunopathol 132:101-108
105. Fang M, Roscoe F, Sigal $L J$ (2010) Age-dependent susceptibility to a viral disease due to decreased natural killer cell numbers and trafficking. J Exp Med 207:2369-2381

106. Robertson MJ, Ritz J (1990) Biology and clinical relevance of human natural killer cells. Blood 76:2421-2438

107. Cooper MA, Fehniger TA, Caligiuri MA (2001) The biology of human natural killer-cell subsets. Trends Immunol 22:633-640

108. Arase H, Saito T, Phillips JH, Lanier LL (2001) Cutting edge: the mouse NK cell-associated antigen recognized by DX5 monoclonal antibody is CD49b (alpha 2 integrin, very late antigen-2). J Immunol 167:1141-1144

109. Chiossone L, Chaix J, Fuseri N, Roth C, Vivier E, Walzer T (2009) Maturation of mouse NK cells is a 4-stage developmental program. Blood 113:5488-5496

110. Storset AK, Kulberg S, Berg I, Boysen P, Hope JC, Dissen E (2004) NKp46 defines a subset of bovine leukocytes with natural killer cell characteristics. Eur J Immunol 34:669-676

111. Mair KH, Essler SE, Patzl M, Storset AK, Saalmüller A, Gerner W (2012) NKp46 expression discriminates porcine NK cells with different functional properties. Eur J Immunol 42:1261-1271

112. Connelley T, Storset AK, Pemberton A, MacHugh N, Brown J, Lund H, Morrison IW (2011) NKp46 defines ovine cells that have characteristics corresponding to NK cells. Vet Res 42:37

113. Walzer T, Jaeger S, Chaix J, Vivier E (2007) Natural killer cells: from CD3(-)NKp46(+) to post-genomics meta-analyses. Curr Opin Immuno 19:365-372

114. Olsen $L$, Åkesson CP, Storset AK, Lacroix-Lamandé S, Boysen P, Metton C, Connelley T, Espenes A, Laurent F, Drouet F (2015) The early intestinal immune response in experimental neonatal ovine cryptosporidiosis is characterized by an increased frequency of perforin expressing NCR1 (+) NK cells and by NCR1(-) CD8(+) cell recruitment. Vet Res 46:28

115. Barakat FM, McDonald V , Di Santo JP, Korbel DS (2009) Roles for NK cells and an NK cell-independent source of intestinal gamma interferon for innate immunity to Cryptosporidium parvum infection. Infect Immun 77:5044-5049

116. Dann SM, Wang HC, Gambarin KJ, Actor JK, Robinson P, Lewis DE, Caillat-Zucman S, White AC Jr (2005) Interleukin-15 activates human natural killer cells to clear the intestinal protozoan Cryptosporidium. J Inf Dis 192:1294-1302

117. Davis WC, Brown WC, Hamilton MJ, Wyatt CR, Orden JA, Khalid AM, Naessens J (1996) Analysis of monoclonal antibodies specific for the gamma delta TcR. Vet Immunol Immunopathol 52:275-283

118. Abrahamsen MS, Lancto CA, Walcheck B, Layton W, Jutila MA (1997) Localization of alpha/beta and gamma/delta T lymphocytes in Cryptosporidium parvum-infected tissues in naive and immune calves. Infect Immun 65:2428-2433

119. Waters WR, Harp JA (1996) Cryptosporidium parvum infection in T-cell receptor (TCR)-alpha- and TCR-delta-deficient mice. Infect Immun 64:1854-1857

120. Banchereau J, Steinman RM (1998) Dendritic cells and the control of immunity. Nature 392:245-252

121. Steinman RM, Hawiger D, Nussenzweig MC (2003) Tolerogenic dendritic cells. Annu Rev Immunol 21:685-711

122. Fogg DK, Sibon C, Miled C, Jung S, Aucouturier P, Littman DR, Cumano A, Geissmann $F$ (2006) A clonogenic bone marrow progenitor specific for macrophages and dendritic cells. Science 311:83-87

123. Schmid MA, Kingston D, Boddupalli S, Manz MG (2010) Instructive cytokine signals in dendritic cell lineage commitment. Immunol Rev 234:32-44

124. McKenna HJ, Stocking KL, Miller RE, Brasel K, De Smedt T, Maraskovsky E, Maliszewski CR, Lynch DH, Smith J, Pulendran B, Roux ER, Teepe M, Lyman SD, Peschon JJ (2000) Mice lacking flt3 ligand have deficient hematopoiesis affecting hematopoietic progenitor cells, dendritic cells, and natural killer cells. Blood 95:3489-3497

125. Waskow C, Liu K, Darrasse-Jèze G, Guermonprez P, Ginhoux F, Merad M, Shengelia T, Yao K, Nussenzweig M (2008) The receptor tyrosine kinase Flt3 is required for dendritic cell development in peripheral lymphoid tissues. Nat Immunol 9:676-683

126. Laouar Y, Welte T, Fu XY, Flavell RA (2003) STAT3 is required for Flt3Ldependent dendritic cell differentiation. Immunity 19:903-912 
127. Steinman RM (1991) The dendritic cell system and its role in immunogenicity. Annu Rev Immunol 9:271-296

128. Perez-Cordon G, Yang G, Zhou B, Nie W, Li S, Shi L, Tzipori S, Feng H (2014) Interaction of Cryptosporidium parvum with mouse dendritic cells leads to their activation and parasite transportation to mesenteric lymph nodes. Pathog Dis 70:17-27

129. Lantier L, Lacroix-Lamandé S, Potiron L, Metton C, Drouet F, Guesdon W, Gnahoui-David A, Le Vern Y, Deriaud E, Fenis A, Rabot S, Descamps A, Werts C, Laurent F (2013) Intestinal CD103+ dendritic cells are key players in the innate immune control of Cryptosporidium parvum infection in neonatal mice. PLoS Pathog 9:e1003801

130. Bedi B, McNair NN, Mead JR (2014) Dendritic cells play a role in host susceptibility to Cryptosporidium parvum infection. Immunol Lett 158:42-51

131. Verschoor CP, Puchta A, Bowdish DM (2012) The macrophage. Methods Mol Biol 844:139-156

132. Choudhry N, Petry F, van Rooijen N, McDonald V (2012) A protective role for interleukin 18 in interferon $\gamma$-mediated innate immunity to Cryptosporidium parvum that is independent of natural killer cells. J Infect Dis 206:117-124

133. Lacroix-Lamandé S, Mancassola R, Naciri M, Laurent F (2002) Role of gamma interferon in chemokine expression in the ileum of mice and in a murine intestinal epithelial cell line after Cryptosporidium parvum infection. Infect Immun 70:2090-2099

134. Pozio E, Rezza G, Boschini A, Pezzotti P, Tamburrini A, Rossi P, Di Fine M, Smacchia C, Schiesari A, Gattei E, Zucconi R, Ballarini P (1997) Clinical cryptosporidiosis and human immunodeficiency virus (HIV)-induced immunosuppression: findings from a longitudinal study of HIV-positive and HIV-negative former injection drug users. J Infect Dis 176:969-975

135. Schmidt W, Wahnschaffe U, Schäfer M, Zippel T, Arvand M, Meyerhans A, Riecken EO, Ullrich R (2001) Rapid increase of mucosal CD4 T cells followed by clearance of intestinal cryptosporidiosis in an AIDS patient receiving highly active antiretroviral therapy. Gastroenterology 120:984-987

136. Zhou L, Chong MM, Littman DR (2009) Plasticity of CD4 + T cell lineage differentiation. Immunity 30:646-655

137. de Graaf DC, Walravens K, Godfroid J, Peeters JE (1998) A Cryptosporidium parvum oocyst low molecular mass fraction evokes a CD4+ T-celldependent IFN-gamma response in bovine peripheral blood mononuclear cell cultures. Int J Parasitol 28:1875-1880

138. Takeda K, Omata Y, Koyama T, Ohtani M, Kobayashi Y, Furuoka H, Matsui T, Maeda R, Saito A (2003) Increase of Th1 type cytokine mRNA expression in peripheral blood lymphocytes of calves experimentally infected with Cryptosporidium parvum. Vet Parasitol 113:327-331

139. Canals A, Pasquali P, Zarlenga DS, Fayer R, Almeria S, Gasbarre LC (1998) Local ileal cytokine responses in cattle during a primary infection with Cryptosporidium parvum. J Parasitol 84:125-130

140. Gomez Morales MA, Ausiello CM, Guarino A, Urbani F, Spagnuolo ML, Pignata C, Pozio E (1996) Severe, protracted intestinal cryptosporidiosis associated with interferon gamma deficiency: pediatric case report. Clin Infect Dis 22:848-850
141. Theodos CM, Sullivan KL, Griffiths JK, Tzipori S (1997) Profiles of healing and nonhealing Cryptosporidium parvum infection in C57BL/6 mice with functional $B$ and T lymphocytes: the extent of gamma interferon modulation determines the outcome of infection. Infect Immun 65:4761-4769

142. Urban JF Jr, Fayer R, Chen SJ, Gause WC, Gately MK, Finkelman FD (1996) $\mathrm{LL}-12$ protects immunocompetent and immunodeficient neonatal mice against infection with Cryptosporidium parvum. J Immunol 156:263-268

143. Korbel DS, Barakat FM, Di Santo JP, McDonald V (2011) CD4 + T cells are not essential for control of early acute Cryptosporidium parvum infection in neonatal mice. Infect Immunol 79:1647-1653

144. Romagnani S (1999) Th1/Th2 cells. Inflamm Bowel Dis 5:285-294

145. Aguirre SA, Perryman LE, Davis WC, McGuire TC (1998) IL-4 protects adult C57BL/6 mice from prolonged Cryptosporidium parvum infection: analysis of CD4+ alpha beta+ IFN-gamma+ and CD4+ alpha beta+ IL-4+ lymphocytes in gut-associated lymphoid tissue during resolution of infection. J Immunol 161:1891-1900

146. McDonald SA, O'Grady JE, Bajaj-Elliott M, Notley CA, Alexander J, Brombacher F, McDonald V (2004) Protection against the early acute phase of Cryptosporidium parvum infection conferred by interleukin-4-induced expression of T helper 1 cytokines. J Infect Dis 190:1019-1025

147. Harrington LE, Hatton RD, Mangan PR, Turner H, Murphy TL, Murphy KM, Weaver CT (2005) Interleukin 17-producing CD4 + effector T cells develop via a lineage distinct from the T helper type 1 and 2 lineages. Nat Immunol 6:1123-1132

148. Stockinger B, Veldhoen M (2007) Differentiation and function of Th17T cells. Curr Opin Immunol 19:281-286

149. Zhao GH, Fang YQ, Ryan U, Guo YX, Wu F, Du SZ, Chen DK, Lin Q (2016) Dynamics of Th17 associating cytokines in Cryptosporidium parvuminfected mice. Parasitol Res 115:879-887

150. Aguirre SA, Mason PH, Perryman LE (1994) Susceptibility of major histocompatibility complex (MHC) class I- and MHC class II-deficient mice to Cryptosporidium parvum infection. Infect Immun 62:697-699

151. Taghi-Kilani R, Sekla L, Hayglass KT (1990) The role of humoral immunity in Cryptosporidium spp. infection. Studies with B cell-depleted mice. J Immunol 145:1571-1576

152. Chen W, Harp JA, Harmsen AG (2003) Cryptosporidium parvum infection in gene-targeted B cell-deficient mice. J Parasitol 89:391-393

153. Wang F, Ekiert DC, Ahmad I, Yu W, Zhang Y, Bazirgan O, Torkamani A, Raudsepp T, Mwangi W, Criscitiello MF, Wilson IA, Schultz PG, Smider WV (2013) Reshaping antibody diversity. Cell 153:1379-1393

154. Allan AJ, Sanderson ND, Gubbins S, Ellis SA, Hammond JA (2015) Cattle NK cell heterogeneity and the influence of MHC class I. J Immunol 195:2199-2206

155. Guzman E, Price S, Poulsom H, Hope J (2012) Bovine $\gamma \delta$ T cells: cells with multiple functions and important roles in immunity. Vet Immunol Immunop 148:161-167

156. Zhang XT, Gong AY, Wang Y, Chen X, Lim SS, Dolata CE, Chen XM (2016) Cryptosporidium parvum infection attenuates the ex vivo propagation of murine intestinal enteroids. Physiol Rep. 4:e13060

\section{Submit your next manuscript to BioMed Central and we will help you at every step:}

- We accept pre-submission inquiries

- Our selector tool helps you to find the most relevant journal

- We provide round the clock customer support

- Convenient online submission

- Thorough peer review

- Inclusion in PubMed and all major indexing services

- Maximum visibility for your research

Submit your manuscript at www.biomedcentral.com/submit 